\title{
A DIAGNOSTIC APPROACH TO MEASURING AND MANAGING WORKPLACE AGGRESSION
}

\author{
PCHARLOTTE PIETERSEN \\ charlottep@ul.ac.za \\ Department of Industrial and Organizational Psychology \\ School of Economics and Management \\ University of Limpopo \\ Sovenga
}

\begin{abstract}
Workplace aggression is an ever-increasing and multi-faceted phenomenon that managers and human resources professionals worldwide will have to address in the twenty first century. A greater awareness of the presence and negative consequences of human aggression in the workplace and the ability to cope with it will become necessary to maintain an effective organization. The purpose of this article is to present an integrated approach to identify and measure aggression in the workplace. The results of a preliminary empirical study are used to demonstrate how the framework can be used for effectively managing different manifestations of workplace aggression.
\end{abstract}

\section{OPSOMMING}

Werksplek aggressie is 'n verskynsel wat wêreldwyd aan die toeneem is en deur bestuur en menslike hulpbronbestuur praktisyns aangespreek sal moet word. 'n Groter bewuswording van die aanwesigheid en negatiewe gevolge van menslike aggressie in die werkplek, sowel as die vermoë om dit suksesvol te hanteer, word belangrik vir voortgesette organisasie-doeltreffendheid. Die doel van die artikel is om 'n ge ¿ntegreerde benadering tot die identifisering en meting van aggressie in die werkplek bekend te stel. Die resultate van 'n voorlopige studie word gebruik om te demonstreer hoe die raamwerk gebruik kan word om verskillende manifestasies van werkplek aggressie doeltreffend te bestuur.

\section{PURPOSE OF THE STUDY}

The increasing presence in the work situation of certain type of behaviours that negatively impact on employees and the organization, which in the extreme manifest itself in incidents of physical assault and violence, is a factor to be reckoned with today by management. There can be little doubt that the occurrence of aggressive behaviour (whether directly or in more subtle forms) in the workplace is detrimental not only to the organization's effectiveness and ongoing operations, but also to the overall quality of life and peace of mind of its employees. Because of the negative impact of workplace aggression on: production costs and lost time (Coco, 1998), interpersonal relations (Andersson \& Pearson, 1999), absenteeism, commitment, organizational departure, organizational functioning (Pearson, Andersson \& Porath, 2000), performance (Zohar, 1999) and employee well-being (Kaukiainen, Salmivalli, Bjorkqvist, Osterman, Lahtinen, Kostamo \& Lagerspelz, 2001) organizations need to deal with the problem. However, before this can happen, management must become aware of and prepare for what Kaukiainen et al. (2001, p. 361) labelled "everyday aggression" and what Neumann and Baron (1998, p.139) defined as "efforts by individuals to harm others with whom they work, or have worked, or the organizations in which they are presently, or were previously, employed".

As a result of the relative novelty of this field of investigation, a uniformly accepted definition of the concept is still lacking. Various terms such as workplace incivility (Andersson \& Pearson, 1999), workplace violence (Myers, 1996; Piturro, 2001) and workplace bullying (Sheehan \& Barker, 1999) are found in the literature. Workplace incivility includes acting rudely or showing disregard for others (Muir, 2000). Workplace violence refers to homicide and violent physical attacks in the workplace (Keim, 1999; Moore, 1997) and bullying in the workplace manifests as psychological violence (Crawford, 1999). These terms denote sub-clusters of aggressive behaviour (Baron, 1998). For this reason, what is

Requests for copies should be addressed to: C Pietersen, charlotte@ul.ac.za believed to be a conceptually more inclusive term, namely workplace aggression (see Neumann \& Baron's definition in the previous paragraph) is adopted in this article.

The main purpose of the paper is to introduce a diagnostic framework that can be used as a management tool to identify problem areas and develop solutions to deal with a range of aggression phenomena in the organization.

\section{LITERATURE REVIEW}

The study of behaviours, such as different forms of aggression and incivility in the workplace, that are detrimental to employees' quality of life and organizational effectiveness has been identified as an important research focus for industrial psychologists and human resource specialists during the first part of the twenty first century (Schrader, 2004). The importance of the topic is underscored by the fact that legislation in, for example, Norway, North America, Australia and Finland clearly indicate the organization's responsibility to manage, for example, workplace bullying (Haslam, 2004; Höel, 2004; Paoli \& Merillie, 2001; Vartia, 2004). South Africa lags behind in this regard. The issue needs to be addressed because aggression in the work context is on the increase and an educated management should be able to recognize and limit aggression, mainly through self-corrective action, worker education and efforts to quickly and effectively deal with aggressive behaviours (Jekielek, Eng \& Koczorowska, 2000).

The mass media tends to focus on noteworthy events such as homicide and suicide in the workplace. However, contrary to the popular press, the majority of aggressive behaviours in the workplace do not involve physical assault rather, they involve aggression that is verbal and covert in nature (Kaukiainen et al. 2001). The attention paid to more overt forms of workplace aggression has resulted in numerous publications to help managers deal with the occurrence of workplace homicide, but scant attention has been paid to day-to-day expressions of more covert (and arguably more costly) forms of workplace aggression (Pearson et al., 2000). 


\section{Forms of workplace aggression}

Neumann and Baron (1998) identified a range of factors that influence different levels of aggression in the workplace. These factors are social, situational, personal, cognitive and attitudinal in nature. A substantial body of research (for instance, Andersson \& Pearson, 1999; Awadalla \& Roughton, 1998; Chen \& Spector, 1992; Geddes \& Baron, 1997; Goulet, 1997; Moore, 1997; Zohar, 1999) suggest that just as personality traits may predispose individuals to respond in a particular way, subtle feelings and thoughts may predispose them to particular forms of behaviour, in this instance to behave aggressively or not. However, for the purpose of the present discussion the focus will be on three empirically derived levels of workplace aggression identified by Baron and Neumann (1996), and not on theoretical issues as such.

\section{Assessing workplace aggression}

Despite the current interest in workplace aggression a research base is only beginning to accumulate and, with the exception of the Neumann and Baron model, the theoretical models available have not been empirically tested (Glomb \& Miner, 2000). The literature also shows that very few measures of workplace aggression have been developed, and then mostly for research purposes. Another problem with assessing the phenomenon is that the instruments used to measure workplace aggression tend to focus either on covert aggression alone (Kaukiainen et al., 2001) or on extreme forms of workplace violence, such as homicide and suicide, instead of a broader spectrum of workplace aggressive behaviours (Neumann \& Baron, 1998). Questionnaires have been developed to assess bullying (Einarsen, Raknes \& Matthiesen, 1994; Quine, 1999). However, bullying is just one form or expression of aggressive behaviour and as such these instruments therefore have limited use. According to Byrnes (2003) one of the reasons why managers do not intervene in cases of workplace aggression before it reach a crisis stage is that they do not have the means for assessing its varied nature and severity of impact in their organizations.

An influential study on different forms of workplace aggression was conducted by Neumann and Baron (1998), in which they rated the frequency with which employees experienced 40 different forms of aggressive behaviour. By means of an exploratory factor analysis, they were able to show that 33 of the variables clustered around three dimensions. These three levels of workplace aggression are labelled: expressions of hostility, obstructionism, and overt aggression (Baron \& Neumann, 1996).

The three levels of workplace aggression (WA), together with a range of factor loadings, identified by Neumann and Baron (1998) are outlined in Figure 1.

LEVEL I: EXPRESSIONS OF HOSTILITY
(factor loadings between .45 and .73) - $\begin{aligned} & \text { Primarily verbal and symbolic behaviour (negative gestures, facial } \\ & \text { expressions, verbal assault). } \\ & \text { - Most frequent form of WA. } \\ & \text { LEVEL II: OBSTRUCTIONISM } \\ & \text { (factor loadings between .52 and .69) } \\ & \text { - Actions that impede a person's ability to perform his/her job. } \\ & \text { - Actions that interfere with the organisation's ability to meet its goals } \\ & \text { and objectives. } \\ & \text { Mostly passive forms of WA (withholding resources and constructive } \\ & \text { behaviours, sabotage, anti-citizenship behaviours, work slowdowns, } \\ & \text { failing to respond appropriately, causing others to delay action, } \\ & \text { showing up late for meetings). } \\ & \text { Rated as more prevalent than acts of overt aggression in the workplace. } \\ & \text { LEVEL III: OVERT AGGRESSION } \\ & \text { (factor loadings between .47 and .74) } \\ & \text { - Acts of workplace violence (attack with weapon; physical assault } \\ & \text { against persons, personal property and company property; theft). }\end{aligned}$

Figure 1: Three-factor model of workplace aggression
The Neumann and Baron rating scale measures only the frequency of occurrence of different forms of aggressive behaviour in the workplace. Although information on the frequency of occurrence of different forms of workplace aggression can be used as a basis for primary intervention, a more productive approach would be to assess workplace aggressive behaviours in a more comprehensive fashion for diagnostic and intervention purposes and to facilitate management action. This can be done by expanding the Neumann and Baron model to include more than just the assessment of frequency of occurrence of aggressive behaviour in the work context.

\section{PROPOSED SOLUTION}

\section{A diagnostic and action framework for managing workplace aggression}

An assessment instrument, the Workplace Aggression Inventory (WAI) was developed by Pietersen and Pietersen (2004). The inventory incorporates selected and suitably modified items from Neumann and Baron (1996). It comprises 72 items using four point Likert-type rating scales for each of the three levels of: hostile, obstructive and overt aggression behaviours, with 24 items for each of the following applications: Perceived frequency of the three levels of workplace aggressive behaviours, intensity of feelings toward (personal impact of) the three levels of workplace aggressive behaviours, and perceived organizational impact of the three levels of workplace aggression behaviours.

Preliminary analysis of the instrument shows encouraging results. Item-scale inter-correlations indicate that WAI items cluster according to the three dimensions of Neumann and Baron's model and, therefore, suggest the usefulness of the questionnaire. In addition, a principle components analysis (exploratory) produced further support for the three dimensions used in the model, with eigen values of 1.20 to 6.00 and a total variance of 75.65 . Reliability values (Cronbach alpha coefficients) range from 0.78 to 0.94 for items in each of the three main groupings and 0.89 for the overall measure.

The instrument was designed to provide information on three interrelated aspects of aggressive behaviour in an organization, namely, its occurrence, its personal as well as perceived organizational impact. The aim is to provide a practical tool that managers can use in a focussed manner to identify, prioritise and deal with different forms of aggressive behaviours occurring in their organizations.

In order to better accomplish these tasks and facilitate the implementation of solutions, another component was added to highlight an active approach to dealing with workplace aggression. For this purpose a standard model of decisionmaking and problem solving in the field of organizational behaviour (Stacey, 1993), is proposed (see Figure 2).

\begin{tabular}{|llll|} 
Step $1 \longrightarrow$ & Step $2 \longrightarrow$ & Step $3 \longrightarrow$ & Step 4 \\
$\begin{array}{l}\text { Problem } \\
\text { awareness }\end{array}$ & $\begin{array}{l}\text { Identify scope } \\
\text { of problem }\end{array}$ & $\begin{array}{l}\text { Identify actions } \\
\text { to solve problem }\end{array}$ & $\begin{array}{l}\text { Activate } \\
\text { solutions }\end{array}$ \\
\hline
\end{tabular}

Figure 2: Steps for managing workplace aggression

In line with this model, workplace aggression can be managed in four basic steps:

Step 1: Problem awareness. Ineffective work operations and critical incidents involving aggressive behaviour can be directed against or involve both the employee in person and/or property. The first step implies that management recognises and acknowledges that workplace aggression is present in the organization. 
Step 2: Identify the scope of the problem. The second step involves determining how prevalent the problem is in the workplace. One way to do this is to establish how aware employees are of workplace aggressive behaviours in the organization. This can be accomplished via the proposed diagnostic framework, by, firstly, measuring the frequency with which different forms of workplace aggression occur in the organization; secondly, how strongly employees feel about the different forms of aggressive behaviour in their workplace (attitudinal content); and, thirdly, what perceived impact different forms of workplace aggression have on the overall operations of the company.

The reason for an expanded approach to the assessment of workplace aggression is that, jointly considered, perception and attitude have greater behavioural significance for remedial purposes, than information about mere frequency of occurrence. In order for management to effectively deal with workplace aggression information is also required on more than just the personal impact of these types of behaviour.

Step 3: Identifying actions to solve the problem. Management, thirdly, needs to choose and implement appropriate corrective and/or proactive actions to minimize the occurrence or recurrence of incidents of aggression in the workplace (Pearson et al., 2000). Some of the areas of action available for this purpose include:

- Recruitment and selection. Human resources practitioners should employ effective and thorough hiring practices (Dunn, 2000; McCune, 1994) to communicate expectations about personal conduct to prospective employees. They also need to identify applicants who may be predisposed to aggressive behaviour, for example by checking job candidates' references thoroughly, especially regarding signals of previous patterns of workplace aggressive behaviour.

- Induction. During job orientation expectations (norms) about interpersonal behaviour in the organization should be carefully communicated to new employees. Information in the form of written policies and procedures regarding workplace aggression should be made available.

- Training. An important way to manage aggressive behaviour in the workplace is through training (see also, Banner, 2001 and Coco, 1998). Training should equip employees with the knowledge and skills to deal with aggression. Interpersonal skills training (for example, in conflict management, the effective use of emotions, negotiation, dealing with difficult people) can enhance workers' ability to early on become aware of and curtail aggressive behaviour before it spirals (Pearson et al., 2000).

- Employee assistance programs. An EAP can be developed to provide counselling to employees - to victims as well as to instigators and witnesses of aggressive behaviour (Moore, 1997).

Step 4: Activating solutions. The last step in the proposed framework is the actual implementation and regular monitoring of corrective and/or proactive actions to manage aggressive behaviours.

\section{Applying the framework: An explanatory example}

The results of an empirical study serve as an example to illustrate how the diagnostic and action-planning framework can be used in an organization. The organization in question is a security company based in the Limpopo Province of South Africa.

Step 1. Management became aware of and acknowledged that aggression was present in the workplace.

Step 2. The Workplace Aggression Inventory was administered to employees in the organization.

Combined rankings for perceived frequency of (Freq.), intensity of feelings toward (Feel.), and perceived impact (Imp.) of different forms of workplace aggressive behaviours on each of the three levels are shown in Table 1 . The lower the rank, the more important the occurrence of a workplace aggressive behaviour in the organization.

\section{TABLE 1}

COMBINED RAMKINGS FOR AGGRESSIVE BEHAVIOURS

\begin{tabular}{|c|c|c|c|}
\hline & $\begin{array}{c}\text { Rank } \\
\text { Freq. }\end{array}$ & $\begin{array}{c}\text { Rank } \\
\text { Feel. }\end{array}$ & $\begin{array}{l}\text { Ran } \\
\text { Imp }\end{array}$ \\
\hline \multicolumn{4}{|l|}{ HOSTILITY } \\
\hline Negative eye-contact & 5,5 & 24 & 24 \\
\hline Belittling behaviour & 11 & 21 & 17.5 \\
\hline Silent treatment & 9 & 22 & 20 \\
\hline Negative non-verbal & 8 & 23 & 22 \\
\hline Rumour/gossip & 1 & 15 & 17,5 \\
\hline Ridicule & 10 & 18,5 & 11 \\
\hline Non-denial of rumours & 2,5 & 20 & 19 \\
\hline Verbal sexual harassment & 12 & 4 & \\
\hline \multicolumn{4}{|l|}{ OBSTRUCTIONISM } \\
\hline Failure to respond (calls, memos) & 13 & 18,8 & 14 \\
\hline Causing work delays & 18 & 15 & 12,5 \\
\hline Failure to warn of physical danger & 4 & 15 & 16 \\
\hline Late for meetings & 5,5 & 11 & 22 \\
\hline Work interference & 15,5 & 17 & 12,5 \\
\hline Resource wastage & 20 & 11 & 15 \\
\hline Denial access to resources & 17 & 8 & 12,5 \\
\hline Intentional work slow-downs & 7 & 8 & \\
\hline \multicolumn{4}{|l|}{ OVERT AGGRESSION } \\
\hline Physical threats & 22 & 2 & \\
\hline Physical Assaults & 24 & 11 & 5,5 \\
\hline Failure to protect others & 20 & 8 & \\
\hline Illegal control of resources (theft) & 2,5 & 5,5 & \\
\hline Destroying mail/messages & 15,5 & 5,5 & \\
\hline Harming employer property & 14 & 3 & 5,5 \\
\hline Harming property of fellow employee & 20 & 5,5 & 10 \\
\hline Attack with weapon & 23 & 1 & \\
\hline
\end{tabular}

In order to help management identify noteworthy combinations of perceived frequency of, intensity of feelings toward, and perceived impact of workplace aggressive behaviours and to use the information to select and activate solutions (Steps 3 and 4 in the diagnostic and action planning framework), the rankings in Table 1 were divided into three groups:

- Rankings 1 to $8=$ High importance.

- Rankings 9 to $16=$ Medium importance.

- Rankings 17 to $24=$ Low importance.

The highlighted rankings in Table 1 allow one to identify different forms of aggression, to prioritise the need for and appropriate type of intervention required, and to monitor the situation in the organization. Because this is an example to demonstrate how management can use information provided by the instrument, only certain rankings are included for discussion. The noteworthy combinations (perceived frequency of, intensity of feelings toward, and perceived impact) for the three levels of workplace aggression are:

Hostile behaviours (workplace aggression - Level 1)

- Similar to the Neumann and Baron (1998) study, the most frequent workplace aggressive behaviour is the occurrence/spreading of rumours. However, despite the finding that this type of behaviour occurred more frequently than any of the other types of aggressive behaviour, the overall intensity of respondents' feelings toward as well as perceived organizational impact of this type of aggressive behaviour were moderate to low in terms of importance. For 
interpretive purposes this type of workplace aggressive behaviour, therefore, does not merit special attention by management.

- A similar interpretation applies to negative eye contact, negative non-verbal cues, and non-denial of rumours, which seems to occur rather frequently but is not personally or organizationally regarded as of much importance. These behaviours do not need serious attention by management in the present case.

- Although there is only moderate occurrence of verbal sexual harassment, respondents do have strong feelings about it and regard it as having high organizational impact. This is, therefore, a form of workplace aggression that needs to be monitored by management, as it may become a disruptive force in future.

Obstructionist behaviours (workplace aggression - Level 2)

- The following obstructionist behaviours have a high frequency of occurrence, but are not regarded as of any great personal and organizational significance, namely, failure to warn of physical danger and being late for meetings. Although these behaviours are not currently high priority items for management action, the results should be of concern to the management and organizational scientist who could suspect a rather apathetic and less than optimal organizational culture. The consultant should therefore engage with management in organizational development interventions to bring about appropriate behavioural changes.

- Much more noteworthy here is the relative high rankings obtained for both frequency of occurrence and perceived personal and organizational impact of intentional work slowdowns. Following the interpretive rationale of the diagnostic framework presented in this article, this type of behaviour requires urgent investigation because it directly impacts on work operations and is a strong indicator of low morale, job dissatisfaction and possibly a poor organizational climate.

Overt aggression (workplace aggression - Level 3)

- With one exception, instances of overt aggression are seen to be infrequent, although (as should be expected according to the theoretical rationale of Neumann and Baron's three-tier model) overt aggression is regarded as a high impact phenomenon for most of the items (Table 1). The good news (again with the noted exception) for management is that these behaviours currently occur minimally in the organization.

- The exception, of course, is the high frequency of illegal control of resources (theft), with a very high ranking of 2.5. Respondents also feel very strongly about the impact (both personally and organizationally) of theft in the organization. Needless to say, this finding requires urgent management attention. A range of measures may be utilized, such as:

- Upgrading staff selection procedures.

- Developing policies and procedures to report and eliminate theft.

- Motivating employees to adhere to it.

- Identifying responsible individuals to control and distribute resources.

- Keeping valuable resources securely under lock and key.

\section{DISCUSSION AND RECOMMENDATIONS}

The purpose of the paper was to introduce and demonstrate the value of a well-founded practical approach to the management of workplace aggression. The approach can be used to help managers prioritise and more effectively focus on workplace aggression behaviours in their organizations. It should also enable management to be more proactive in preventing the workplace from deteriorating or work processes becoming disrupted as a result of aggression.

It is believed that the proposed diagnostic and action-planning framework can be employed to help managers deal with workplace aggression in a focussed and constructive manner. The model will also be useful to sensitise staff to the existence of a variety of workplace aggressive behaviours detrimental to organizational effectiveness, through their negative impact/influence on work performance and quality of work life.

The model can be applied in various settings. Future research could also, for instance, include investigating the relationship between workplace aggression and other factors such as psychological well-being, quality of work life, performance and organizational commitment.

\section{REFERENCES}

Andersson, L.M. \& Pearson, C. (1999). Tit for tat? The spiralling effect of incivility in the workplace. Academy of Management Review, 24 (3), 452-472.

Awadalla, C.A. \& Roughton, J.E. (1998). Workplace violence prevention: The new safety focus. Professional Safety, 43 (12), 31-35.

Banner, S. (2001). HELL in your hallways. Journal of Property Management, 66 (1), 52- 56.

Barron, O. (1998). Bullying at work: The distinction between workplace bullying and workplace violence and the ramification for OHS. Journal of Occupational Health and Safety, Australia and New Zealand, 14 (6), 575-580.

Baron, R.A. \& Neumann, J.H. (1996). Workplace violence and workplace aggression: Evidence on their relative frequency and potential causes. Aggressive Behaviour, 22, 161-173.

Byrnes, J.D. (2003). The aggression continuum: A paradigm shift. Occupational Health and Safety, 69 (2), 70-71.

Chen, P.Y. \& Spector, P.E. (1992). Relationships of work stressors with aggression, withdrawal, theft and substance use. Journa of Occupational \& Organizational Psychology, 65 (4), 177-184.

Coco, M.P. (1998). The new war zone: The workplace. S.A.M. Advanced Management Journal, 63 (1), 15-21.

Crawford, N. (1999). Conundrums and confusion in organizations: The etymology of the word "bully". International Journal of Manpower, 20 (1), 86-93.

Dunn, K. (2000). Bullying in the workplace often goes unnoticed. Workforce, 79 (4), 28-29.

Einarsen, S., Raknes, B.I. \& Matthiesen, S.B. (1994). Bullying and harassment at work and their relationships to work environment quality: an exploratory study. European Work and Organisational Psychologist, 4 (4), 381-401.

Geddes, D. \& Baron, R.A. (1997). Workplace aggression as a consequence of negative performance feedback. Management Communication Quarterly, 10 (4), 433-455.

Glomb, T.M. \& Miner, A.G. (2000). Workplace anger, aggression, and affect: Using Affective Events Theory as an interpretive framework. Paper presented in the symposium: Anger at Work: Conceptual and Methodological Extensions Second International Conference on Emotions in Organizational Life, 10 August: Toronto.

Goulet, L.R. (1997). Modelling aggression in the workplace: The role of role models. Academy of Management Executive, 11 (2), 84-86.

Haslam, I. (2004). Welcome to hell's office. Community Care, $1538,49$.

Höel, H. (2004). Violence and harassment in European workplaces: Trends and political responses. Keynote address presented at the $4^{\text {th }}$ International Conference on Bullying and Harassment in the Workplace, 28-29 June, Bergen, Norway.

Jekielek, J., Eng, P. \& Koczorowska, M. (2000). Educating management in combating low-level aggression in the workplace. XIV World Meeting: Prevention and control of aggression and the impact on its victims, 9-14 July, University of Valencia, Spain.

Kaukiainen, A., Salmivalli, C., Bjorkqvist, K., Osterman, K., Lahtinen, A., Kostamo, A. \& Lagerspelz, K. (2001). Overt and convert aggression in work settings in relation to the subjective well-being of employees. Aggressive Behaviour, 27, 360-371. 
Keim, J. (1999). Workplace violence and trauma: A 21st century rehabilitation issue. Journal of Rehabilitation, 65 (1), 16-20.

McCune, J.C. (1994). Companies grapple with workplace violence. Management Review, 83 (3), 52-57.

Moore, L.R. (1997). Preventing homicide and acts of violence in the workplace. Professional Safety, 42 (7), 20-23.

Muir, C. (2000). Can we all get along? The interpersonal challenge at work. Academy of Management Executive, 14 (4), 143-144.

Myers, D.W. (1996). The mythical world of workplace violence-or is it? Business Horizons, 39 (4), 31-36.

Neumann, J.H. \& Baron, A. (1998). Workplace violence and workplace aggression: Evidence concerning specific forms, potential causes, and preferred targets. Journal of Management, 24 (3), 391-420.

Paoli, P, \& Merillie, D. (2001). Third European survey on working conditions 2000, European Foundation for the Improvement of Living and Working Condition. Luxembourg: Office for Official Publication for the European Communities.

Pearson, C.M., Andersson, L.M. \& Porath, C.L. (2000). Assessing and attacking workplace incivility. Organizational Dynamics, 29 (2), 123-138.

Pietersen, H.J. \& Pietersen, C. (2004). Workplace aggression inventory. Unpublished research instrument. University of
Limpopo: Department of Industrial and Organizational Psychology.

Piturro, M. (2001). Workplace violence. Strategic Finance, 82 (11), 35-38.

Quine, L. (1999). Workplace bullying in NHS community trust: Staff questionnaire survey. British Medical Journal, 318 (7178), 228-232.

Schrader, B. (2004). Industrial/Organizational Psychology 2010: A Research Odyssey, Chapter 3. Retrieved October 18, 2004, from the World Wide Web: http://teachpsych.lemoyne.edu/ teachpsych/faces/text/Ch03.htm

Sheehan, M. \& Barker, M. (1999). Applying strategies for dealing with workplace bullying. International Journal of Manpower, 20 (1), 50-57.

Stacey, R.D. (1993). Strategic management and organisational dynamics. London: Pitman Publishing.

Vartia, M. (2004). Research, practice and increased awareness: The Finnish experience. Keynote address presented at the 4th International Conference on Bullying and Harassment in the Workplace, 28-29 June, Bergen, Norway.

Zohar, D. (1999). When things go wrong: The effect of daily work hassles on effort, exertion and negative mood. Journal of Occupational and Organizational Psychology, 72 (3), 265-283. 